\title{
GCU
}

Glasgow Caledonian

University

University for the Common Good

\section{Re-embedding Embeddedness: What is the role of Social Enterprise in Promoting Democracy and Protecting Social Rights?}

Roy, Michael J.; Dey, Pascal; Teasdale, Simon

Published in:

Social Enterprise Journal

DOI:

10.1108/SEJ-02-2021-0011

Publication date:

2021

Document Version

Author accepted manuscript

Link to publication in ResearchOnline

Citation for published version (Harvard):

Roy, MJ, Dey, P \& Teasdale, S 2021, 'Re-embedding Embeddedness: What is the role of Social Enterprise in Promoting Democracy and Protecting Social Rights?', Social Enterprise Journal, vol. 17, no. 3, pp. 379-397. https://doi.org/10.1108/SEJ-02-2021-0011

\section{General rights}

Copyright and moral rights for the publications made accessible in the public portal are retained by the authors and/or other copyright owners and it is a condition of accessing publications that users recognise and abide by the legal requirements associated with these rights.

Take down policy

If you believe that this document breaches copyright please view our takedown policy at https://edshare.gcu.ac.uk/id/eprint/5179 for details of how to contact us. 


\title{
Re-embedding Embeddedness: What is the role of Social Enterprise in Promoting Democracy and Protecting Social Rights?
}

\author{
Michael J. Roy ${ }^{\mathrm{a}}$, Pascal Dey ${ }^{\mathrm{b}}$ and Simon Teasdale ${ }^{\mathrm{a}}$ \\ ${ }^{a}$ Yunus Centre for Social Business and Health \\ Glasgow Caledonian University, UK \\ bInstitut Innovation and Entrepreneurship \\ Bern University of Applied Sciences, Switzerland
}

Corresponding Author: michael.roy@gcu.ac.uk

Authors' pre-publication version. Please cite as:

Roy, M. J., Dey, P., \& Teasdale, S. (2021). Re-Embedding Embeddedness: What Is the Role of Social Enterprise in Promoting Democracy and Protecting Social Rights? Social Enterprise Journal. https://doi.org/10.1108/SEJ-02-2021-0011 


\section{ABSTRACT}

Purpose

In today's 'market society' almost every aspect of our everyday lives is shaped by market forces. In this essay, we focus on the potential role of social enterprise as one means of reembedding the economy into society: to ensure the economy works for people, rather than the other way around.

\section{Design/methodology/approach}

This is primarily a conceptual paper: a provocation.

\section{Findings}

We argue that to work as an embedding force, social enterprise needs to ensure both reciprocity and market exchange, while acting in a way that attempts to compensate for the retreat of the state through providing public services and promoting collective decision-making and public deliberation.

\section{Originality}

Drawing upon the work of Karl Polanyi to conceptualise social enterprise as an 'alternative' economic actor within a plural economic system, we contribute to on-going debates about social enterprise as an alternative way of organising markets and society. We highlight the challenges involved in achieving such a vision and suggest ways these might be overcome.

Keywords: Social Enterprise, Polanyi, Embeddedness, Welfare, Democracy, Organisations 


\section{INTRODUCTION}

In contrast to the time during which Karl Polanyi wrote his seminal treatise The Great Transformation (1944) we have witnessed an epochal shift from the post-WWII welfare state to a 'capitalist state' system predicated on the desideratum of capital, where the state acts as the de facto enabler of the self-regulating market (Jessop, 2002). Such a shift has been witnessed in many advanced liberal societies, but especially in the United Kingdom, where we have experienced over a decade of welfare state retrenchment through austerity policies justified by the Great Financial Crisis (Clarke and Newman, 2012). Indeed, explanations for why many parts of the population of the UK have been especially vulnerable to the effects of the COVID-19 pandemic have pointed to austerity and disinvestment in a range of vital public services - not restricted to public health provision - over a prolonged period leading up to the crisis (Chakelian and Goodier, 2020). Our present 'COVID-19 interregnum' (Springer, 2020) thus forces us to take stock and reflect on how market forces have come to shape almost every aspect of our everyday lives - what Polanyi termed the 'market society' - with significant deleterious consequences for both people and nature. These include unprecedented levels of economic inequality, the return of populism and 'strongman' politicians, climate crisis and ongoing civil unrest.

Our aim in this essay is to provocatively outline a situation whereby social enterprise, as an 'alternative' form of economic organising (Fuller et al., 2010; Mair and Rathert, 2019) could potentially serve as a form of counterbalance to the intrusion of markets into our daily lives, and thus as the basis for a 're-embedded' economy, i.e. an economy which is instituted in line with the broader needs and demands of society. Drawing illustrations and examples from the UK, which is recognised as having the most developed institutional environment for social enterprise in the world (see Nicholls, 2010; Teasdale, 2012), our arguments are undertaken in a tradition of utopian thinking exemplified by Polanyi (Aulenbacher et al., 2019; Novy, 2017; 
Wright, 2012). We consider that such work is needed to balance recent critiques of social enterprise as merely an 'embodiment' of neoliberal reason, or even as a form of 'neoliberal social movement' (Spicer et al., 2019). Although we value critical research shedding light on how social enterprise can be co-opted to perpetuate existing conditions of economic, social and political inequality (Kreitmeyr, 2019; Roy and Hackett, 2017), our intention in this paper is to rethink, re-imagine, and perhaps even 'rehabilitate' social enterprise (Eynaud et al., 2019; Kay et al., 2016) as an emancipatory actor in a human-centred 'plural' economy (Laville, 2010). More explicitly, we ask: what would a Polanyian vision for social enterprise look like? And how could it work to promote democracy and the protection of social rights?

To begin to answer such questions, we propose an approach that embraces Polanyi's core concept of 'embeddedness' to unpack the conditions under which social enterprises might help facilitate the democratic organisation of society: embedding economic activity in noneconomic values, instead of merely securing the conditions for capital accumulation through its inclusion in the matrix of welfare provision. Taking our theoretical cues from Polanyi, our basic argument holds that alternative forms of economic organising, such as social enterprise, cannot serve 'merely' as economic actors, but also as political actors that arrogate to themselves at least some of the functions historically held by welfare states (Hussain \& Moriarty, 2014; Jessop, 2002).

There are four main parts to our essay. First, a brief review of extant research is provided which highlights the need for a normative account of the broader role that social enterprises play in the interplay between economy and society. Second, we summon Polanyi's work, and particularly the notion of embeddedness, as our normative framework to emphasise that the economy should be immersed in socio-political relations to effectively contribute to the expression of the public interest. Applying Polanyi's work to our subject matter, we then infer three broad ways in which social enterprises can work to promote democracy and the protection 
of social rights, consistent with the social economy tradition: a) the provision of public services guided by the principles of reciprocity and redistribution (as opposed to private profit); b) collective decision-making; and c) public deliberation. Fourth, we conclude our essay by discussing the challenges involved in bringing about the wider institutional conditions through which such a social economy could flourish. Here we identify a paradox that those working at the micro level of the organisation (including both academics and activists) have been unable to address: If social enterprise is to compensate for the retreat of the state in its role as welfare provider (Stephan et al., 2015), who will guarantee or protect the enforcement of the means necessary to sustain such efforts to re-embed the economy into society? Finally, we sketch out ways that this challenge might be overcome. But first we must turn our attention to recent research on 'contemporary' social enterprise.

\section{THE PROBLEM WITH 'CONTEMPORARY’ SOCIAL ENTERPRISE}

Since the late 1990s, management scholars have increasingly turned their attention towards social enterprises as problem-oriented ways of doing business, instigating positive social change by striking a balance between economic and social/ecological value creation. The basic thinking here is that individual social enterprises bring the efficiency of markets to bear upon social problems that neither the state nor traditional charities can solve (Dey and Teasdale, 2016); the implication being that, under conditions characterised by, for instance, poverty, malnutrition, lack of medical care or housing, social enterprises can together address the 'institutional void' instigated by state (and/or market) failures (Dacin et al., 2010; Estrin et al., 2013; Mair and Marti, 2009; Stephan et al., 2015). This view sees 'contemporary' social enterprises as emerging from, and working in, contexts of 'institutional failure' or 'institutional incongruence' (Mair and Rathert, 2019) where no effective formal institutional support systems exist (Mair et al., 2012), thus implicitly or explicitly treating social enterprises as a 
counterbalance to the failure of states and/or mainstream markets to adequately secure public welfare (see Roy \& Hackett, 2017).

According to Schieffer and Lessem (2009, p. 717) "social enterprises have established themselves primarily to counterbalance the shortcomings of the private and public sectors". Leaving aside, at least for the time being, whether or not social enterprises can ever be an adequate counterbalance in such circumstances, welfare state retrenchment has certainly played a constitutive role in the evolution of contemporary social enterprise (Garrow and Hasenfeld, 2014). This is particularly the case in the domain of social service provision. The weakening of the state does not only lead to an undersupply or lack of supply of particular goods or services (pertaining to education, health, mobility and so on) but also to a democratic deficit: a decline in political participation or decision-making (Eikenberry and Kluver, 2004). By implication, if the role of social enterprise is reduced to counterbalancing state failure in securing welfare through the provision of goods and services, this tends to neglect the potential role that social enterprises ought to play in facilitating a healthy democratic civil society and the protection of social rights (Horn, 2013). Others have argued that (many) social enterprises are too closely aligned with the logics of the market (Dart, 2004, p. 411) and thus can often integrate market logics into communities and areas of life that did not previously operate in this way (Mair and Marti, 2009), weakening society by subordinating social issues, interests and demands to business and management-related objectives (Hjorth, 2013). Similarly, much contemporary social enterprise scholarship adopts too narrow a perspective of what 'social enterprise' involves (Stephan et al., 2016), within an equally narrow framing of what 'the economy' means (Peredo and McLean, 2010). Polanyi calls this 'the economistic fallacy' (Polanyi, 1977): viewing the world through a narrow lens that restricts what we conceive as 'the economy' to market-based activity alone. Furthermore, much (management) scholarship on social enterprise places the 'social' and the 'economic' on a dyadic; set up in opposition to 
one another (see Child, 2019). From a Polanyian perspective, such treatment reinforces the notion that the economy and society are separate (or 'disembedded') from each other (Peck, 2013; Pike et al., 2000). The idea that 'contemporary' social enterprise could act as a counterbalancing force to market fundamentalism is thus, at best, problematic (Roy and Grant, 2020; Roy and Hackett, 2017).

However, the attentive reader will have noticed our prefix 'contemporary'. This signifies that there is an older - social economy - tradition (see Amin, 2009; Utting, 2015) that we consider may have potential to serve as a democratic protector of the public interest and guarantee social rights while serving as the basis for an embedded economy. While contemporary management literature on social enterprise has, in the main, chosen to ignore considerations about the economy's embeddedness, we make the case for redirecting attention to some of the foundational work of social enterprise, notably the social economy literature. According to Defourny and Develtere (1999, p. 16):

The social economy includes all economic activities conducted by enterprises, primarily cooperatives, associations and mutual benefit societies, whose ethics convey the following principles:

1. placing service to its members or to the community ahead of profit;

2. autonomous management;

3. a democratic decision-making process;

4. the primacy of people and work over capital in the distribution of revenues.

Through such a lens, social enterprise is conceived of as an alternative to the mainstream capitalist enterprise, with deliberately counterhegemonic, emancipatory potential (dos Santos \& Banerjee, 2019; Peredo \& McLean, 2010). The defining principles of social economy organisations identified by Defourny and Develtere serve as a reminder that it would be far too simplistic to reduce social enterprise to 'simply' an instrument of neoliberalism; doing so forecloses its radical aims, failing to recognise that many social enterprises, particularly in (but 
not restricted to) the global south, exist as a solidarity-based response to neoliberal colonisation.

But if the social economy tradition of social enterprise is to contribute to (re-)embedding the economy (Vastenaekels and Pelenc, 2018), this raises intricate normative questions: How can social enterprise compensate for the unfulfilled role of the state in securing social protection? Or, more specifically, (how) can social enterprises employ market mechanisms while remaining connected to the democratic fabric of society (Evers \& Laville, 2004; Laville, 2010)? Other theorists have discussed similar questions in relation to embeddedness before. What distinguishes our contribution, however, is that the notion of embeddedness we adopt derives from Polanyian (meta) theory, before being applied to the organisational level. In developing organisational theory from meta-theory, we are necessarily prompted to examine the implications of our argument (and this is where existing work is lacking) at the societal level. To begin this process, we next turn our attention to Polanyi's key ideas.

\section{EMBEDDEDNESS, DOUBLE MOVEMENT AND THE STATE}

Concerned with the collapse of 'nineteenth century civilization' and 'the political and economic origins of this event' (Polanyi, 1944, p. 3), Polanyi's work traced the cataclysms of the early twentieth century - the First World War, the Great Depression and the rise of fascism - to market fundamentalism (Block \& Somers, 2014). He argued that a market economy assumes an institutional separation of society into an economic and a political sphere, with the maxim that no policy should interfere. But the economy, he remarks, is always

embedded and enmeshed in institutions, economic and noneconomic. The inclusion of the noneconomic is vital. For religion or government may be as important for the structure and functioning of the economy as monetary institutions or the availability of tools and machines themselves that lighten the toil of labor. (Polanyi, 1957, p. 250)

To treat the economy as if it is (or can be) 'disembedded' - set apart and elevated above sociopolitical forces - as advocates of the self-regulating market economy insist, is simply to 
misunderstand how markets work, he argued: markets are necessarily part of society and cannot operate properly without the legitimation and structures that the state and societal norms provide, nor the protection that states, societal structures and institutions can offer from various crises and negative social impacts of market systems. Polanyi did not seek to explain the functionings of market exchange in order to explain the social preconditions for market efficiency; he was, rather, concerned with what happens to social order and political freedom when economic exchange is organised principally through the idea of self-regulating markets (Beckert, 2011).

Polanyi's notion of embeddedness is most fully set out in his essay The Economy as Instituted Process (Polanyi, 1957). He argues that all economies - past and present - are embedded and enmeshed in social relations and institutions, but also describes market exchange and market economy as self-regulating and disembedded, which reveals some of the tensions, contradictions (Gemici, 2007) and even paradoxes (Dale, 2010) in his thinking. Block (2001, p. xxiii) argues in his introduction to the 2001 edition of The Great Transformation that "the logical starting point for explaining Polanyi's thinking is his concept of embeddedness. Perhaps his most famous contribution to social thought, this concept has also been a source of enormous confusion." This seeming contradiction has certainly precipitated a number of authors, but most notably Granovetter (1985), to develop their own take on the concept, meaning that the concept of embeddedness has undergone something of a 'great transformation' (Beckert, 2011) of its own. Polanyi termed the process by which action is taken to re-embed the economy as one part of a 'double movement' where society acts to remedy the devastating social consequences of the self-regulating market. Although the state is considered to have a central role in the reembedding process, he did not (and nor do we) restrict attention to the state alone. Polanyi observed that, for example, political parties and social movements tend to coalesce around either side of a fault line, with those favouring deregulating markets and extending 
commodification on the one side and a 'broad-based, cross-class front, including urban workers and rural landowners, socialists and conservatives, that sought to 'protect society from the ravages of the market' (Fraser, 2013, p. 120) on the other:

While on the one hand markets spread all over the face of the globe and the amount of goods involved grew to unbelievable dimensions, on the other hand a network of measures and policies was integrated into powerful institutions designed to check the action of the market relative to labour, land and money [...] a deep seated movement sprang into being to resist the pernicious effects of a market-controlled economy. (Polanyi, 1944, pp. 79-80)

Although Polanyi conceived the state as a primary force in re-embedding the economy in society, he also conceded that the state is inherently ambiguous, forming an object of contradictory relations of force and ideologies (i.e. 'the principle of economic liberalism' versus 'the principle of social protection'; Polanyi 1944, p. 132). He remained aware of the coercive power of the state and its co-implication with the market economy (which it helped to create), pointing out that "institutional procedures and rights could be established that would effectively prevent the state's coercive power from being used in ways that were illegitimate or designed to preserve the position of particular individuals or interests" (Block, 2008, p. 10). An effective way of curtailing the state's coercive power, it could be argued, is to establish possibilities for public deliberation within the general populace.

Polanyi's concept of embeddedness also exhorts us not to limit our attention to the conditions that have to exist in society - including politically, for the purpose of economic efficiency attention must also be paid to the dialectical relationships involved between the local (micro) organisational context, the national (meso) political economic system (or 'the economy'), and the international (macro) global capitalist system. All of these layers are intertwined and thus embedded within society: they are, after all, societal constructs that are analytically distinct but intimately entangled in practice. As an example, Dale (2008) reminds us that in Polanyi's concept of the double movement (and, indeed, in his concept of embeddedness), there are 
several contradictions and tensions that deserve closer reading. He brings attention to the ongoing struggle between market expansion and protectionism which 'became entangled with a developing dichotomy between national and international spheres' (Dale, 2008, p. 499). We can draw upon this example of 'multi-layered' embeddedness to consider how globalization and neoliberalism affect 'everyday' interactions (Ban, 2016; Hobson and Seabrooke, 2010) and vice versa. Polanyi's ideas have helped us to understand that struggles for social protection not only occur in a specific global context, but "how social struggles within particular polities were constrained and limited by the nation's particular position within the global system of states" (Block, 2008, p. 3).

Furthermore, rather than working to ameliorate the worst effects of supposedly 'free' markets on individuals and communities, we have seen that the state in many advanced liberal societies, especially those adhering to a neoliberal approach (Jessop, 2002), has chosen to reduce much of its power to regulate, resulting in, one could argue, "the fragmentation of authority, the increasing ambiguity of borders and jurisdictions; and the blurring of the lines between the public and the private sphere" (Kobrin, 2009, p. 350); a time that Habermas (2001) refers to as the 'post-national constellation'. Theorists from the realm of corporate social responsibility have highlighted that this decline is in some ways compensated for by an emergence of new forms of global governance beyond the level of the state. Transnational NGOs, civil society groups, and private businesses, often in cooperation with state authorities, have started to fill gaps in the global regulation and provision of public services. Despite ongoing criticisms of CSR, and the inevitably of its failure to address the failings of the capitalist system (Schneider, 2019), we have seen corporations become actively engaged in political activities (a turn that has been dubbed 'political corporate social responsibility' or 'political CSR' for short: see Scherer et al. 2016), to advance their (often explicit) aim to advance their vision of the common good. Notwithstanding that there should be some kind of referential normative framework for 
this intention, and an adherence to accepted non-market norms, optimistically this has been described as corporations moving beyond their own narrow self-interest to, for instance, provide public services where state authorities are no longer willing or able to fulfil such functions. Scherer et al., (2016, p. 276) refer to a wide variety of different areas in which private corporations have started to act as quasi-political organisations, including in the fields of "public health, education, and public infrastructure, the enforcement of social and environmental standards along supply chains or the fight against global warming, corruption, discrimination or inequality."

It is within such local/global (or micro/macro) interactions that the potential of the social economy to act as an alternative to mainstream market economy, as a "model for restoring community and democratic participation" (Amin et al., 2003, p. 28) must be critically examined. Scholars close to the EMES community of scholars have put forward social enterprise as a de facto 'operationalisation' of Polanyi's 'substantive' vision of the economy; that is, "an instituted process of interaction" between people and their environment "which results in a continuous supply of want satisfying material means" (Polanyi, 1957, p. 248):

By following Polanyi and his 'substantive approach' to the economy, we argue that social enterprises combine the economic principles of market, redistribution and reciprocity and hybridize these three types of economic exchange so that they work together rather than in isolation from each other. (Defourny and Nyssens, 2006, pp. 1011)

However, while such 'Polanyian hybridity' (Roy and Grant, 2020) provides an alternative perspective on hybrid forms of organising than has been the focus of much of the literature on social enterprise to date (see Doherty, Haugh, \& Lyon, 2014), the question of how such organisations can work to re-embed the economy into society is still to be sufficiently theorized.

The essence of our argument to this point can therefore be summarised as follows: the capitalist state in many advanced liberal societies can no longer be relied upon to instigate the 
countermovement that, Polanyi argued, was required to prevent societal upheaval, crises, and environmental devastation instigated through the free reign of market forces. In response, theorists of different persuasions have been calling for organisations in both civil society and mainstream business to become active in the political realm. As our reading of 'contemporary' social enterprise literature shows, however, such a development may well prove problematic for democracy. Polanyi's idea of embeddedness thus forms an injunction to suggest that economic principles, other than market exchange alone, and, indeed, non-economic principles such as collective decision making and public deliberation, are needed to make market-based activities remain connected to the democratic organisation of society. We have argued that the social economy tradition of social enterprise offers potential in this area and will now use the next section to sketch three concrete ways through which democracy and protect social rights may be promoted through social enterprises.

\section{THREE ROUTES TO EMBEDDEDNESS: PROVISION OF PUBLIC SERVICES, COLLECTIVE DECISION-MAKING, AND PUBLIC DELIBERATION}

In this section we elaborate on Polanyi's notion of 'embeddedness' in conjunction with three distinct activities, namely: provision of public services; collective decision-making; and public deliberation, which, when taken together, can expand and deepen democracy "so that markets are ultimately subordinated to democratic politics" (Block, 2018, p. 212).

\section{Provision of Public Services}

[in] the absence of the motive of gain; the absence of the principle of laboring for remuneration; the absence of the principle of least effort; and, especially, the absence of any separate and distinct institution based on economic motives [...] how, then, is order in production and distribution ensured? The answer is provided in the main by two principles of behavior not primarily associated with economics: reciprocity and redistribution. (Polanyi, 1944, p. 47)

In many countries, including the UK, there has been a much greater involvement of social enterprise in public service provision in recent decadesw. The basic premise for this is that it 
reduces the costs of public services while increasing their quality, since social enterprises supposedly pursue a 'value creation' strategy which maximises benefits for beneficiaries. While this view is in line with most current views of how social enterprise is supposed to work, this optimism is not always justified.

The term 'mission drift' has been used to describe the situation where the social mission of the social enterprise is jeopardised if the business or market logic takes over (Cornforth, 2014). For example, Alexander et al. (1999, p. 460) found in their study of social service non-profit organisations that market-oriented organisations had shifted their focus from areas such as undertaking research, teaching, advocacy, and supporting poor people, to meeting individual client demand based on ability to pay. Thus, given that contemporary social enterprises often differ quite significantly with regard to their profit motive and their business models, it is pertinent to assume that many organisations rely on value capture as their primary strategy (Driver, 2012; Martin and Osberg, 2007). This value creation versus capture trade-off is central to the choice of the activities to be performed by the organisation (and not just their price level or quantity). The example used by Santos (2012, p. 338) is a case in point:

a pharmaceutical company focused on value capture would not invest in vaccines for diseases that plague developing countries due to the lack of ability to pay by its potential clients. In contrast, a pharmaceutical company focused on value creation would have a motivation to invest in that activity, independent of the amount of value that it would be able to capture, given the strong and measurable impact for society of disease eradication.

Management scholars have approached mission drift mainly as an organisational or communicative problem which can be solved through adequate structural solutions (Battilana \& Lee, 2014). From a Polanyian perspective a more authoritative approach would be needed to make sure that organisations working in the social economy are locked on the side of value creation precisely because such a strategic orientation prevents mission drift through avoiding profit maximisation. This could be achieved through, say, (de jure or de facto) non-distribution 
constraints (Hansmann, 1980). The non-distribution constraint makes sure that profits are reinvested in the social purpose instead of being re-distributed to 'individuals who exercise control of it [the organisational entity], such as members, officers, directors, or trustees' (Hansmann, 1980, p. 838). Similarly, another protection against mission drift is the 'asset lock', which prohibits the distribution of residual assets to members: consider cases of for-profit social businesses eventually taken over by private companies, who are not committed to social goals: a notable example being the sale of Ben and Jerry's Ice Cream to Unilever (Young et al., 2012). The purpose of asset locks is to ensure that the public or community benefit of any social investment is maintained and cannot be for private benefit. Similar to non-distribution constraints, asset locks are often stipulated by law with respect to certain organisational forms, such as (in the UK) charities, community benefit societies or, most recently, Community Interest Companies. Alternatively, organisations with different legal forms, or in different legal environments, might seek to stipulate an asset lock within their Memoranda and/or Articles of Association, providing assurance that capital will not be reappropriated or 'captured' for private gain. Asset locks and profit distribution constraints ensure that social economy organisations are tilted towards value creation rather than value capture. However, these measures only ensure that the primacy of capital is counterbalanced, rather than ensuring that markets are subordinated to broader political interests.

\section{Collective Decision-Making}

The second approach - collective decision-making - relates closely to the paradigm of the commons (Ostrom, 1990) which is considered to have considerable potential for a radical break with the 'economistic fallacy' (Polanyi, 1977; see also Hann, 2014). Tarinski (2018, p. 1) notes that

The practices of 'commoning' are deeply rooted in social deliberation and communitarian relationships. It is not solely concerned with narrow questions of 
production and consumption, and in fact imbues them with ethical and political characteristics.

Polanyi's embrace of guild socialism after the First World War (Dale, 2016) was based on a firm rejection of the 'depersonalization' of labour (Van Buren III et al., 2021) into a fictitious commodity; workers having control over production "with industrial self-government seen as indispensable to enable working people to cultivate their desire to serve their community and develop higher moral characters" (Dale 2016, p. 22). This point is echoed by Mendell (2007, p. 81) when she speaks of the potential of actors within civil society, through a process of economic democratisation, to influence policy outcomes through a process of institutionalisation of practices, which are then 'transmitted across institutional sub-systems and vertically to macro or governing institutions.' Democratic processes within organisations can also function as a necessary source of interrogation of assumptions and taken-for-granted practices, a type of argumentation that Kock (2009) refers to as 'dissensus-oriented discourse'. The introduction of democratic processes and principles (e.g. Rochdale principle 'one worker/member, one vote') can foster participation in, and reorientation of, public policymaking, stimulate learning through exchange, and promote justice through collective decision-making: in essence, a form of 'solidarity-based associationism' (Laville and Eynaud, 2019). Polanyi recognised such actions as a form of 'collectivist countermovement' against market fundamentalism:

The great variety of forms in which the "collectivist" countermovement appeared was not due to any preference for socialism or nationalism on the part of concerted interests, but exclusively to the broader range of the vital social interests affected by the expanding market mechanism. (Polanyi, 1944, p. 145)

Like asset locks and non-distribution principles, it is also possible to legally enshrine formal democratic processes in an organisation's constitution. In the UK, most legal forms of organisation are amenable to embedding cooperative principles within their Articles of Association. Additionally, legal forms such as the Industrial and Provident Society and 
Community Benefit Society formally enshrine one-member one vote within the legal structure of the organisation (Smith and Teasdale, 2012).

However, democratisation of internal decision-making, ownership and collaboration mechanisms within the social economy does not, in itself, guarantee that social enterprises will then contribute to democratic solidarity at a societal level (Ruebottom, 2018). Indeed, some scholars warn of the dangers of simply moving from a model of 'shareholder dictatorship' (Stout, 2012) to one of 'worker dictatorship' (or 'dictatorship of proletariat') as envisaged under Soviet-style communism. Early in the twentieth century Rosa Luxemburg recognised the perils facing co-operatives when they are forced to adopt the clothes of capitalism to survive in the capitalist market (echoing our discussion of 'mission drift' earlier):

The workers forming a co-operative in the field of production are thus faced with the contradictory necessity of governing themselves with the utmost absolutism. They are obliged to take toward themselves the role of capitalist entrepreneur-a contradiction that accounts for the usual failure of production co-operatives which either become pure capitalist enterprises or, if the workers' interests continue to predominate, end by dissolving. (Luxemburg, 2012 [1908], p. 47)

Although democratic governance models are considered to lead to increased democratic participation (Le Roux, 2009) and even freedom from domination (Griffin et al., 2015), such contexts are regularly charicatured as like being in an 'endless meeting' (Polletta, 2004), a situation that is probably inimical to the type of enterprise and innovation that social enterprises strive for. We do know, however, that new forms of collective spaces for economic and political democracy are currently being envisaged, such as 'hybrid forums' where experts and lay people discuss controversial socio-technical issues (Callon et al., 2011). It is not beyond our imagination to consider that such experiments in democracy could be operationalised through collective forms of social enterprise. From a Polanyian perspective, we consider that social enterprise can only be an effective space for social protection if there is a meaningful link to wider public deliberation and democracy building (Eikenberry, 2018; Horn, 2013), 
where the social enterprise is implicitly or explicitly connected to political activism through social movements (Hockerts, 2006). It perhaps goes without saying that linking social enterprise with public deliberation has not yet been sufficiently explored in extant literature.

\section{Public Deliberation}

While the foregoing discussion has chiefly dealt with social enterprises' ability to embed the economic process, we should not lose sight of the primary role of the state (in a wellfunctioning democracy) in ensuring the diffusion of deliberative democratic culture across all levels of socio-economic life. But - drawing on Polanyi's (1947) recognition that the process of disembedding the economy from society creates a 'no man's land' between politics and economics - Birchfield (1999, p. 47) explains that:

politics is the vehicle of public deliberation whereby genuine social compromises may be reached and those forces beyond the direct control of ordinary citizens may at least be contested and made accountable. If market ideology prevails, the very ideals of democracy are put into jeopardy as the mythic ideal of the free market trumps the real potential of politics.

Most scholars have been reluctant to consider private organisations as promoters of public deliberation. Relatedly, most liberal theories of democracy would suggest that democracy lies outside the sphere of influence of private actors, linked to occasional political processes rather than everyday life decisions (Deetz, 1992). It is thereby worth recalling that democratic solidarity is an essential concept for effective resistance to a society based on market principles (Dacheux and Goujon, 2011). In response, a small number of scholars have drawn upon theories of deliberative democracy to argue that market actors in the social economy (Horn, 2013) and even in the mainstream economy (Scherer, 2018; Scherer and Palazzo, 2011) should be an active part of political deliberation.

Deliberative democracy is a big tent, containing a variety of approaches (Kahane et al., 2013). The element most relevant for our current theorising is the focus of deliberative democracy on 
"explicit participation in public processes of political will formation" (Scherer and Palazzo, 2011, p. 1108). From this perspective, non-state actors such as found in the social economy should be democratically accountable by deliberating about collective issues, decisions and rules with stakeholders (Crane et al., 2004). Such deliberative processes can take different forms, and they often require the creation of specific arrangements, actively involving various kinds of social actors

from invited spaces - whether open door or with selected participants - to spaces that are claimed by mobilized citizens and groups. The institutional designs of deliberations reflect both the capacity and the aims of the convening organisations (be they governments, civil society organisations, businesses or others). The particular goals of deliberative democratic processes can include generative exercises aimed at surfacing perspectives and ideas; citizen or cross-sectoral collaboration on community-based action; popular education or mobilization; inter-communal understanding; and/or policy development. (Kahane et al., 2013, pp. 3-4)

What one is bound to see here is that the theory of deliberative democracy offers a normative account of how organisations in the social economy can gain procedural legitimacy by giving voice and power to beneficiaries, consumers and various other stakeholders in decisionmaking. Of course, some social economy organisations might in fact practice (or try to practice) deliberative democracy. But not all do. And whereas the provision of public services and internal democracy might be protected through asset locks and formally democratic (internal) organisational and governance structures, it is more difficult to find examples as to how organisations might guarantee deliberative democratic processes. Lessons from consumer coops and multi-stakeholder co-ops may well offer some insights, as will, undoubtedly, the rapidly-emerging Fair Shares Model ${ }^{i}$ developed by Ridley-Duff (2015) and colleagues. But even these examples usually only give voice to those directly impacted, raising questions as to what happens to broader stakeholder groups not directly served. Furthermore, as dos Santos \& Banerjee (2019, p. 3) identify: 
It is also noteworthy that even when social enterprises come closer to effective democratic control and collective ownership - that is, the most emancipatory format may be assumed - they seem not to be consistent enough to handle the political embeddedness of popular everyday economies.

\section{DISCUSSION AND CONCLUSION}

We have provided some examples of how social enterprises, at least those from the social economy tradition, can be thought of as a counterbalancing force: if not bringing the Keynesian welfare state back in, then at least arrogating to itself some of the functions of the post-WWII states. States that, for all intents and purposes, have abdicated themselves of responsibility for undertaking a critical check on market fundamentalism. A reinvigorated recognition of the important role of actors in the social economy to a well-functioning democracy will hopefully provoke a discussion on the nature of reciprocity beyond the unit of the family to the level of communities, cities, countries and even at a transnational level (albeit Polanyi himself gave no example of large-scale reciprocity - see Hodgson, 2017). We can also consider the potential for 'socialising' (re-embedding in the Polanyian sense) market-oriented businesses and systems. While it is perhaps far too optimistic to believe that the entire capitalist system, which is enacted quite differently around the globe, can be turned around to ensure that it works for society, rather than the other way around, there is, in fact, evidence that change is afoot, even in the unlikeliest of places. The IMF's recognition of its past role in increasing global inequality and subsequent programmes to address this; or the increasing centrality of discussions concerning the role of business in addressing social issues, inequality and climate change and, indeed, social enterprise and social investment at the annual World Economic Forum in Davos. We have seen mainstream management journals exploring the potential for social enterprise to be a central player in dealing with the crisis and reconstruction efforts post COVID-19 (Bacq and Lumpkin, 2021) and also social enterprise and the social economy being framed as a powerful actor supporting efforts to 'build back better' and reshape and rethink the post-crisis 
economy (OECD, 2020). In recent times we have seen even quite large businesses transform themselves into social enterprises (for example the Cordant Group - one of the UK's largest recruitment firms - has introduced a fixed limit on the gap between its highest- and lowestpaid employees and a ceiling on dividends). While one should remain vigilant and critical of the intentions of such groups, and the potential for 'greenwashing', there are, we admit, genuine grounds for optimism.

Indeed, Polanyi wrote in the aftermath of some of the greatest crises the world has ever seen and yet The Great Transformation is, at its heart, optimistic. A plethora of institutions were, at the time of his writing, being constructed, brought about by the post war consensus to guarantee stability, fairness and social protection for all. However, the dangers of market fundamentalism are once again as acute now as they were during Polanyi's time:

Now, as then, a relentless push to extend and de-regulate markets is everywhere wreaking havoc - destroying the livelihoods of billions of people; fraying families, weakening communities and rupturing solidarities; trashing habitats and despoiling nature across the globe. Now, as then, attempts to commodify nature, labour and money are destabilizing society and economy. (Fraser, 2013, p. 119)

Many institutions once considered impregnable are instead facing ongoing crises, while the protective measures implemented by $20^{\text {th }}$ century welfare states (arguably one of the key achievements of the post-WWII era) and the gains of progressive social movements have, in places, been noticeably weakened or even unravelled by austerity policies precipitated by the Great Financial Crisis. As Block (2008, p. 4) astutely observes, 'when a nation's economy first starts into a downturn, supporters of laissez-faire are often successful in demanding a rollback of previous reforms that they claimed discouraged productive investment', a process that acts to ensure the ongoing hegemony of neoliberalism (Crouch, 2011).

While there is considerable attention paid in academia to the potential of social enterprise to help build a more socially-just economic system (Driver, 2012), what this economic system might look like, and indeed what social enterprise currently looks like, is considerably 
contested. Drawing on Polanyi's theory of embeddedness, we have argued that in many countries the state, particularly those with a neoliberal prospect, no longer performs the role of 'insulating the fabric of social life from the destructive impact of market pressures' (Block, 2008). Building on those theorists who have argued that social economy actors might fill some of the gaps vacated by the state in the $21^{\text {st }}$ century, and drawing upon the work of Polanyi, we wanted to ascertain: what would a Polanyian vision for social enterprise look like, and how would it work to promote democracy and the protection of social rights?

We have shown how the provision of public services, economic democracy, and (to a limited extent) deliberative democracy might be pursued through social enterprise. Indeed, the first two of these can be legally enshrined within organisational forms in many countries, guaranteeing protection against a movement towards the market such as through legal constraint in profit distribution, an asset lock and a formal democratic decision-making structure. The more difficult challenge for social enterprise is in acting as a guarantor of deliberative democracy. Nonetheless, a duty to consult can be enshrined in law. It is notable that the Public Services (Social Value) Act in England, for example, compels commissioners of public services to consult with public stakeholders (where appropriate). 'Soft' law such as voluntary commitments or codes of conduct can also enshrine a commitment to deliberative democracy ${ }^{\mathrm{ii}}$. However, while it would seem more difficult to enforce or guarantee these duties, it is not beyond the bounds of possibility to believe that others will pick up our challenge and help develop mechanisms for ensuring this.

A bigger problem, however, is that legal mechanisms designed to guarantee protection from the market can only be constituted and enforced by the state: the very same state (one could reasonably argue) that we have abandoned somewhat in the desire to theorise an embedded/embedding social economy. This may not be a problem for some institutional theorists who have (unsurprisingly) focused the bulk of their attention at the organisational 
level (Stephan et al., 2016). As we have outlined, there is an implicit belief that the existence of organisations operating in the social economy at an aggregate level will be strong enough to translate into positive social change.

It was tempting to close our own essay by showing what a Polanyian vision of a truly embedding social economy would look like without paying attention to the wider ecosystem in which they would operate. But even normative theorists must pay attention to existing contingencies and practical challenges at times. Our work opens a paradox that may not be solved, at least within the present political-economic framework. If, as we have shown, organisations operating within the social economy require guarantees to protect various rights against market fundamentalism, then who will guarantee the legal enforcement of these guarantees? The same state that has been captured by the forces of market fundamentalism?

And finally, let us move this normative argument towards its natural extension. In some countries, such as the UK, legal forms exist (and have existed in some form for centuries) which already protect democratic rights against market fundamentalism at the individual level (Smith and Teasdale, 2012). Suffice to say, many organisations operating within the social economy have not necessarily fared well against their (more) capitalist competitors. Most of the Building Societies and Friendly Societies of $19^{\text {th }}$ and $20^{\text {th }}$ century Britain have demutualised or have been taken over by private banks. Notable exceptions can be found globally, but these serve, in the main, to illustrate the possibility of a different world.

Social enterprises therefore require protection in the marketplace, such as through favourable taxation treatment, employment subsidies, and so on. Some scholars have begun to focus on how markets might be reshaped to favour pro-social activities, whether through favourable treatment by commissioners of public services (Teasdale et al., 2012) or through the creation of instruments such as Social Impact Bonds (Edmiston and Nicholls, 2018; Maier and Meyer, 2017; Roy et al., 2017). But, at best, this only creates a protected space for those organisations 
delivering goods and services commissioned by the state (in some form or other). Polanyi's focus, was however, on the role of the economy on the whole of society, rather than just in niche areas.

There remains a societal level problem, though, regarding what it means for social enterprises and those 'more social' projects to not just live alongside but often in the shadow of spheres of the economy that are actively destructive, or, at best unsupportive, of people and the planet. Social enterprise may indeed be alternative sites of economic action, embodying alternative principles (Gibson-Graham, 2008; Gibson-Graham and Cameron, 2007), but unless they are capable of not just holding their own alongside the state and market but exercising some countervailing influence over those spheres, then social enterprise may be destined to remain subordinate, if not marginal.

Nevertheless, our essay has highlighted that the social economy could potentially act as a site for securing social protection and connection to the democratic organisation of society. The potential of social enterprise may only be realised when the state, or the functions of the state, have been reclaimed, with the economy re-oriented to work for the benefit of people and our environment; a true 'wellbeing economy' (Costanza et al., 2018; Roy, 2021), in other words. Social enterprise scholars must, therefore, work with scholars of politics and democracy to develop in tandem this (perhaps somewhat) utopian vision, and so our plea is to develop a new scientific interface at the nexus of organisational studies and political economy. Work at such an interface might focus on how organisational behaviour could potentially change the wider political economic system, a democratic re-capture of the state - a form of countermovement, if you will - in order to guarantee the conditions under which a renewed vision for the economy could flourish. 


\section{REFERENCES}

Alexander, J., Nank, R. and Stivers, C. (1999), "Implications of Welfare Reform: Do Nonprofit Survival Strategies Threaten Civil Society?”, Nonprofit and Voluntary Sector Quarterly, Vol. 28 No. 4, pp. 452-475.

Amin, A. (Ed.). (2009), The Social Economy: International Perspectives on Economic Solidarity, Zed Books, London.

Amin, A., Cameron, A. and Hudson, R. (2003), "The Alterity of the Social Economy”, in Leyshon, A., Lee, R. and Williams, C.C. (Eds.), Alternative Economic Spaces, SAGE Publications Ltd, Thousand Oaks, CA, pp. 27-54.

Aulenbacher, B., Bärnthaler, R. and Novy, A. (2019), "Karl Polanyi, The Great Transformation, and Contemporary Capitalism", Österreichische Zeitschrift Für Soziologie, Vol. 44 No. 2, pp. 105-113.

Bacq, S. and Lumpkin, G.T. (2021), “Social Entrepreneurship and COVID-19”, Journal of Management Studies, Vol. 58 No. 1, pp. 285-288.

Ban, C. (2016), Ruling Ideas: How Global Neoliberalism Goes Local, Oxford University Press, New York, NY.

Battilana, J. and Lee, M. (2014), “Advancing Research on Hybrid Organizing - Insights from the Study of Social Enterprises", The Academy of Management Annals, Vol. 8 No. 1, pp. 397-441.

Beckert, J. (2011), “The Great Transformation of Embeddedness: Karl Polanyi and the New Economic Sociology", in Hann, C. and Hart, K. (Eds.), Market and Society: The Great Transformation Today, Cambridge University Press, Cambridge, pp. 38-55.

Birchfield, V. (1999), “Contesting the Hegemony of Market Ideology: Gramsci's 'Good Sense' and Polanyi's 'Double Movement'”, Review of International Political Economy, Vol. 6 No. 1, pp. 27-54. 
Block, F.L. (2001), "Introduction", The Great Transformation: The Political and Economic Origins of Our Time, Second Beacon Paperback Edition Published in 2001., Beacon Press, Boston, MA, pp. xviii-xxxviii.

Block, F.L. (2008), "Polanyi’s Double Movement and the Reconstruction of Critical Theory”, Revue Interventions Économiques. Papers in Political Economy, No. 38, available at: http://interventionseconomiques.revues.org/274 (accessed 20 August 2014).

Block, F.L. (2018), Capitalism: The Future of an Illusion, University of California Press, Oakland, California.

Block, F.L. and Somers, M.R. (2014), The Power of Market Fundamentalism: Karl Polanyi's Critique, Harvard University Press, Cambridge, MA.

Callon, M., Lascoumes, P. and Barthe, Y. (2011), Acting in an Uncertain World: An Essay on Technical Democracy, translated by Burchell, G., MIT Press, Cambridge, MA, available at: https://mitpress.mit.edu/books/acting-uncertain-world (accessed 13 July 2019).

Chakelian, A. and Goodier, M. (2020), "Ten Years of Data Reveal How Austerity Weakened the Uk's Pandemic Response", 1 July, available at: https://www.newstatesman.com/2020/07/ten-years-data-reveal-how-austerityweakened-uk-s-pandemic-response (accessed 18 February 2021).

Child, C. (2019), "Whence Paradox? Framing Away the Potential Challenges of Doing Well by Doing Good in Social Enterprise Organizations”, Organization Studies, available at:https://doi.org/doi.org/10.1177/0170840619857467.

Clarke, J. and Newman, J. (2012), “The Alchemy of Austerity”, Critical Social Policy, Vol. 32 No. 3, pp. 299-319. 
Cornforth, C. (2014), "Understanding and Combating Mission Drift in Social Enterprises”, Social Enterprise Journal, Vol. 10 No. 1, pp. 3-20.

Costanza, R., Caniglia, B., Fioramonti, L., Kubiszewski, I., Lewis, H., Lovins, L.H., McGlade, J., et al. (2018), “Toward a Sustainable Wellbeing Economy”, The Solutions Journal, Vol. 9 No. 2, p. 5.

Crane, A., Matten, D. and Moon, J. (2004), "Stakeholders as Citizens? Rethinking Rights, Participation, and Democracy", Journal of Business Ethics, Vol. 53 No. 1, pp. 107122.

Crouch, C. (2011), The Strange Non-Death of Neoliberalism, Polity Press, Cambridge.

Dacheux, E. and Goujon, D. (2011), "The Solidarity Economy: An Alternative Development Strategy?”, International Social Science Journal, Vol. 62 No. 203-204, pp. 205-215.

Dacin, P.A., Dacin, M.T. and Matear, M. (2010), “Social Entrepreneurship: Why We Don't Need a New Theory and How We Move Forward From Here”, The Academy of Management Perspectives, Vol. 24 No. 3, pp. 37-57.

Dale, G. (2008), “Karl Polanyi's the Great Transformation: Perverse Effects, Protectionism and Gemeinschaft”, Economy and Society, Vol. 37 No. 4, pp. 495-524.

Dale, G. (2010), “Social Democracy, Embeddedness and Decommodification: On the Conceptual Innovations and Intellectual Affiliations of Karl Polanyi”, New Political Economy, Vol. 15 No. 3, pp. 369-393.

Dale, G. (2016), Reconstructing Karl Polanyi, Pluto Press, London.

Dart, R. (2004), “The Legitimacy of Social Enterprise”, Nonprofit Management and Leadership, Vol. 14 No. 4, pp. 411-424.

Deetz, S. (1992), Democracy in an Age of Corporate Colonization: Developments in Communication and the Politics of Everyday Life, SUNY Press, Albany, NY. 
Defourny, J. and Develtere, P. (1999), "Social Economy: The Worldwide Making of a Third Sector”, in Defourny, J., Develtere, P. and Fonteneau, B. (Eds.), Social Economy. North and South, De Boeck Supérieur, Bruxelles, pp. 25-56.

Defourny, J. and Nyssens, M. (2006), “Defining Social Enterprise”, in Nyssens, M. (Ed.), Social Enterprise: At the Crossroads of Market, Public Policies and Civil Society., Routledge, Abingdon, Oxon, pp. 3-26.

Dey, P. and Teasdale, S. (2016), “The Tactical Mimicry of Social Enterprise Strategies: Acting 'As If' in the Everyday Life of Third Sector Organizations”, Organization, Vol. 23 No. 4, pp. 485-504.

Doherty, B., Haugh, H. and Lyon, F. (2014), “Social Enterprises as Hybrid Organizations: A Review and Research Agenda", International Journal of Management Reviews, Vol. 16 No. 4, pp. 417-436.

Driver, M. (2012), “An Interview with Michael Porter: Social Entrepreneurship and the Transformation of Capitalism", Academy of Management Learning \& Education, Vol. 11 No. 3, pp. 421-431.

Edmiston, D. and Nicholls, A. (2018), "Social Impact Bonds: The Role of Private Capital in Outcome-Based Commissioning”, Journal of Social Policy, Vol. 47 No. 1, pp. 57-76. Eikenberry, A.M. (2018), “Social Entrepreneurship and Democracy”, in Dey, P. and Steyaert, C. (Eds.), Social Entrepreneurship: An Affirmative Critique, Edward Elgar Publishing Limited, Cheltenham, pp. 210-229.

Eikenberry, A.M. and Kluver, J.D. (2004), "The Marketization of the Nonprofit Sector: Civil Society at Risk?", Public Administration Review, Vol. 64 No. 2, pp. 132-140.

Estrin, S., Mickiewicz, T. and Stephan, U. (2013), “Entrepreneurship, Social Capital, and Institutions: Social and Commercial Entrepreneurship Across Nations", Entrepreneurship Theory and Practice, Vol. 37 No. 3, pp. 479-504. 
Evers, A. and Laville, J.-L. (2004), The Third Sector in Europe, Edward Elgar Publishing, Cheltenham.

Eynaud, P., Laville, J.-L., dos Santos, L.L., Banerjee, S., Avelino, F. and Hulgård, L. (Eds.). (2019), Theory of Social Enterprise and Pluralism: Social Movements, Solidarity Economy, and Global South, Routledge, New York; Abingdon.

Fraser, N. (2013), “A Triple Movement?: Parsing the Politics of Crisis After Polanyi”, New Left Review, No. 81, pp. 119-132.

Fuller, D., Jonas, A.E.G. and Lee, R. (Eds.). (2010), Interrogating Alterity: Alternative Economic and Political Spaces, Ashgate, Farnham, Surrey ; Burlington, VT.

Garrow, E.E. and Hasenfeld, Y. (2014), "Social Enterprises as an Embodiment of a Neoliberal Welfare Logic", American Behavioral Scientist, Vol. 58 No. 11, pp. 14751493.

Gemici, K. (2007), "Karl Polanyi and the Antinomies of Embeddedness", Socio-Economic Review, Vol. 6 No. 1, pp. 5-33.

Gibson-Graham, J.K. (2008), "Diverse Economies: Performative Practices for 'Other Worlds", Progress in Human Geography, Vol. 32 No. 5, pp. 613-632.

Gibson-Graham, J.K. and Cameron, J.A. (2007), "Community Enterprises: Imagining and Enacting Alternatives to Capitalism”, Social Alternatives, Vol. 26 No. 1, pp. 20-25. Granovetter, M. (1985), "Economic Action and Social Structure: The Problem of Embeddedness", American Journal of Sociology, Vol. 91 No. 3, pp. 481-510.

Griffin, M., Learmonth, M. and Elliott, C. (2015), "Non-Domination, Contestation and Freedom: The Contribution of Philip Pettit to Learning and Democracy in Organisations", Management Learning, Vol. 46 No. 3, pp. 317-336.

Habermas, J. (2001), “Constitutional Democracy: A Paradoxical Union of Contradictory Principles?", Political Theory, Vol. 29 No. 6, pp. 766-781. 
Hann, C. (2014), “The Economistic Fallacy and Forms of Integration Under and After Socialism", Economy and Society, Vol. 43 No. 4, pp. 626-649.

Hansmann, H.B. (1980), “The Role of Nonprofit Enterprise”, The Yale Law Journal, Vol. 89 No. 5, pp. 835-901.

Hjorth, D. (2013), "Public Entrepreneurship: Desiring Social Change, Creating Sociality”, Entrepreneurship \& Regional Development, Vol. 25 No. 1-2, pp. 34-51.

Hobson, J.M. and Seabrooke, L. (2010), "Everyday International Political Economy”, in Blyth, M. (Ed.), Routledge Handbook of International Political Economy (IPE): IPE as a Global Conversation, Routledge, Abingdon, Oxon, pp. 290-306.

Hockerts, K. (2006), “Entrepreneurial Opportunity in Social Purpose Business Ventures”, in Mair, J., Robinson, J. and Hockerts, K. (Eds.), Social Entrepreneurship, Palgrave Macmillan, New York, pp. 142-154.

Hodgson, G.M. (2017), “Karl Polanyi on Economy and Society: A Critical Analysis of Core Concepts”, Review of Social Economy, Vol. 75 No. 1, pp. 1-25.

Horn, D.M. (2013), Democratic Governance and Social Entrepreneurship: Civic Participation and the Future of Democracy, Routledge, Abingdon, Oxon.

Hussain, W. and Moriarty, J. (2014), “Corporations, the Democratic Deficit, and Voting”, Georgetown Journal of Law \& Public Policy, Vol. 12, pp. 429-437.

Jessop, B. (2002), The Future of the Capitalist State, Polity, Cambridge, UK : Malden, MA.

Kahane, D., Loptson, K., Herriman, J. and Hardy, M. (2013), "Stakeholder and Citizen Roles in Public Deliberation", Journal of Public Deliberation, Vol. 9 No. 2, p. Article 2.

Kay, A., Roy, M.J. and Donaldson, C. (2016), “Re-Imagining Social Enterprise”, Social Enterprise Journal, Vol. 12 No. 2, pp. 217-234. 
Kobrin, S.J. (2009), "Private Political Authority and Public Responsibility: Transnational Politics, Transnational Firms, and Human Rights”, Business Ethics Quarterly, Vol. 19 No. 3, pp. 349-374.

Kock, C.E.J. (2009), “Constructive Controversy: Rhetoric as Dissensus-oriented Discourse”, Cogency, Vol. 1 No. 1, pp. 89-112.

Kreitmeyr, N. (2019), "Neoliberal Co-Optation and Authoritarian Renewal: Social Entrepreneurship Networks in Jordan and Morocco", Globalizations, Vol. 16 No. 3, pp. 289-303.

Laville, J.-L. (2010), "Plural Economy”, in Hart, K., Laville, J.-L. and Cattani, A.D. (Eds.), The Human Economy, Polity Press, Cambridge, pp. 77-83.

Laville, J.-L. and Eynaud, P. (2019), "Rethinking Social Enterprise Through Philanthropic and Democratic Solidarities”, in Eynaud, P., Laville, J.-L., dos Santos, L.L., Banerjee, S., Avelino, F. and Hulgård, L. (Eds.), Theory of Social Enterprise and Pluralism: Social Movements, Solidarity Economy, and Global South, Routledge, New York; Abingdon, pp. 18-43.

Le Roux, K. (2009), "Paternalistic or Participatory Governance? Examining Opportunities for Client Participation in Nonprofit Social Service Organizations", Public Administration Review, Vol. 69 No. 3, pp. 504-517.

Luxemburg, R. (2012), Reform or Revolution and Other Writings, Dover, Mineola, NY.

Maier, F. and Meyer, M. (2017), "Social Impact Bonds and the Perils of Aligned Interests", Administrative Sciences, Vol. 7 No. 3, p. 24.

Mair, J., Battilana, J. and Cardenas, J. (2012), “Organizing for Society: A Typology of Social Entrepreneuring Models", Journal of Business Ethics, Vol. 111 No. 3, pp. 353-373. Mair, J. and Marti, I. (2009), "Entrepreneurship in and Around Institutional Voids: A Case Study from Bangladesh”, Journal of Business Venturing, Vol. 24 No. 5, pp. 419-435. 
Mair, J. and Rathert, N. (2019), “Alternative Organizing with Social Purpose: Revisiting Institutional Analysis of Market-Based Activity”, Socio-Economic Review, available at:https://doi.org/10.1093/ser/mwz031.

Martin, R.L. and Osberg, S. (2007), "Social Entrepreneurship: The Case for Definition”, Stanford Social Innovation Review, Vol. Spring 2007, pp. 28-39.

Mendell, M. (2007), “Karl Polanyi and Instituted Process of Economic Democratization”, in Harvey, M., Ramlogan, R. and Randles, S. (Eds.), Karl Polanyi: New Perspectives on the Place of the Economy in Society, Manchester University Press, Manchester, pp. $78-92$.

Nicholls, A. (2010), “Institutionalizing Social Entrepreneurship in Regulatory Space: Reporting and Disclosure by Community Interest Companies", Accounting, Organizations and Society, Vol. 35 No. 4, pp. 394-415.

Novy, A. (2017), “Emancipatory Economic Deglobalisation: A Polanyian Perspective”, Revista Brasileira de Estudos Urbanos e Regionais, Vol. 19 No. 3, p. 554.

OECD. (2020), Social Economy and the COVID-19 Crisis: Current and Future Roles, OECD Publishing, Paris, available at: http://www.oecd.org/coronavirus/policyresponses/social-economy-and-the-covid-19-crisis-current-and-future-roles-f904b89f/ (accessed 3 November 2020).

Ostrom, E. (1990), Governing the Commons: The Evolution of Institutions for Collective Action, Cambridge University Press, Cambridge; New York.

Peck, J. (2013), “Disembedding Polanyi: Exploring Polanyian Economic Geographies”, Environment and Planning A: Economy and Space, Vol. 45 No. 7, pp. 1536-1544.

Peredo, A.M. and McLean, M. (2010), "Indigenous Development and the Cultural Captivity of Entrepreneurship", Business \& Society, Vol. 52 No. 4, pp. 592-620. 
Pike, A., Lagendijk, A. and Vale, M. (2000), “Critical Reflections on 'Embeddedness' in Economic Geography: The Case of Labour Market Governance and Training in the Automotive Industry in the North East Region of England”, Restructuring Industry and Territory: The Experience of Europe's Regions, TSO, London, pp. 59-82.

Polanyi, K. (1944), The Great Transformation: The Political and Economic Origins of Our Time, Second Beacon Paperback Edition Published in 2001., Beacon Press, Boston, MA.

Polanyi, K. (1947), “Our Obsolete Market Mentality: Civilization Must Find a New Thought Pattern", Commentary, Vol. 3, pp. 109-117.

Polanyi, K. (1957), “The Economy as Instituted Process”, in Polanyi, K., Arensberg, C.M. and Pearson, H.W. (Eds.), Trade and Market in the Early Empires: Economies in History and Theory, Free Press, Glencoe, IL, pp. 243-269.

Polanyi, K. (1977), The Livelihood of Man, edited by Pearson, H.W., Academic Press, New York.

Polletta, F. (2004), Freedom Is an Endless Meeting: Democracy in American Social Movements, University of Chicago Press, Chicago.

Ridley-Duff, R. (2015), The Case for FairShares: A New Model for Social Enterprise Development and the Strengthening of the Social and Solidarity Economy, CreateSpace Independent Publishing Platform, Charleston, available at: http://shura.shu.ac.uk/10198/1/TheCaseForFairSharesV1.2-SHU.pdf.

Roy, M.J. (2021), “Towards a 'Wellbeing Economy': What Can We Learn from Social Enterprise?", in Gidron, B. and Domaradzka, A. (Eds.), The New Social and Impact Economy: An International Perspective, Springer International Publishing, Cham. 
Roy, M.J. and Grant, S. (2020), “The Contemporary Relevance of Karl Polanyi to Critical Social Enterprise Scholarship", Journal of Social Entrepreneurship, Vol. 11 No. 2, pp. 177-193.

Roy, M.J. and Hackett, M.T. (2017), “Polanyi's 'Substantive Approach' to the Economy in Action? Conceptualising Social Enterprise as a Public Health 'Intervention'”, Review of Social Economy, Vol. 75 No. 2, pp. 89-111.

Roy, M.J., McHugh, N. and Sinclair, S. (2017), "Social Impact Bonds - Evidence-Based Policy or Ideology?”, in Greve, B. (Ed.), Handbook of Social Policy Evaluation, Edward Elgar Publishing Ltd, Northampton, MA, pp. 263-275.

Ruebottom, T. (2018), "Deliberative Democracy in Social Entrepreneurship: A Discourse Ethics Approach to Participative Processes of Social Change", in Dey, P. and Steyaert, C. (Eds.), Social Entrepreneurship: An Affirmative Critique, Edward Elgar Publishing Limited, Cheltenham, pp. 191-209.

Santos, F.M. (2012), “A Positive Theory of Social Entrepreneurship”, Journal of Business Ethics, Vol. 111 No. 3, pp. 335-351.

dos Santos, L.L. and Banerjee, S. (2019), "Social Enterprise: Is It Possible to Decolonise This Concept?”, in Eynaud, P., Laville, J.-L., dos Santos, L.L., Banerjee, S., Avelino, F. and Hulgård, L. (Eds.), Theory of Social Enterprise and Pluralism: Social Movements, Solidarity Economy, and Global South, Routledge, New York; Abingdon, pp. 3-17.

Scherer, A.G. (2018), “Theory Assessment and Agenda Setting in Political CSR: A Critical Theory Perspective", International Journal of Management Reviews, Vol. 20 No. 2, pp. $387-410$.

Scherer, A.G. and Palazzo, G. (2011), “The New Political Role of Business in a Globalized World: A Review of a New Perspective on CSR and its Implications for the Firm, 
Governance, and Democracy”, Journal of Management Studies, Vol. 48 No. 4, pp. 899-931.

Scherer, A.G., Rasche, A., Palazzo, G. and Spicer, A. (2016), "Managing for Political Corporate Social Responsibility: New Challenges and Directions for PCSR 2.0”, Journal of Management Studies, Vol. 53 No. 3, pp. 273-298.

Schieffer, A. and Lessem, R. (2009), "Beyond Social and Private Enterprise: Towards the Integrated Enterprise", Transition Studies Review, Vol. 15 No. 4, pp. 713-725.

Schneider, A. (2019), "Bound to Fail? Exploring the Systemic Pathologies of CSR and Their Implications for CSR Research”, Business \& Society, pp. 1-19.

Smith, G. and Teasdale, S. (2012), “Associative Democracy and the Social Economy: Exploring the Regulatory Challenge", Economy and Society, Vol. 41 No. 2, pp. 151176.

Spicer, J., Kay, T. and Ganz, M. (2019), "Social Entrepreneurship as Field Encroachment: How a Neoliberal Social Movement Constructed a New Field”, Socio-Economic Review, Vol. 17 No. 1, pp. 195-227.

Springer, S. (2020), "Caring Geographies: The COVID-19 Interregnum and a Return to Mutual Aid”, Dialogues in Human Geography, SAGE Publications, Vol. 10 No. 2, pp. $112-115$.

Stephan, U., Patterson, M., Kelly, C. and Mair, J. (2016), “Organizations Driving Positive Social Change: A Review and an Integrative Framework of Change Processes”, Journal of Management, Vol. 42 No. 5, pp. 1250-1281.

Stephan, U., Uhlaner, L.M. and Stride, C. (2015), "Institutions and Social Entrepreneurship: The Role of Institutional Voids, Institutional Support, and Institutional Configurations”, Journal of International Business Studies, Vol. 46 No. 3, pp. 308331. 
Stout, L.A. (2012), The Shareholder Value Myth: How Putting Shareholders First Harms Investors, Corporations, and the Public, Berrett-Koehler Publishers, San Francisco, CA.

Tarinski, Y. (2016), "Beyond Economism: The Prospect of the Commons", New Compass, 10 August, available at: http://new-compass.net/articles/beyond-economism-prospectcommons.

Teasdale, S. (2012), "What's in a Name? Making Sense of Social Enterprise Discourses”, Public Policy and Administration, Vol. 27 No. 2, pp. 99-119.

Teasdale, S., Alcock, P. and Smith, G. (2012), "Legislating for the Big Society? The Case of the Public Services (Social Value) Bill’, Public Money \& Management, Vol. 32 No. 3, pp. 201-208.

Utting, P. (Ed.). (2015), Social and Solidarity Economy: Beyond the Fringe?, Zed Books, London.

Van Buren III, H.J., Schrempf-Stirling, J. and Westermann-Behaylo, M. (2021), “Business and Human Trafficking: A Social Connection and Political Responsibility Model”, Business \& Society, Vol. 60 No. 2, pp. 341-375.

Vastenaekels, J. and Pelenc, J. (2018), "Investigating the Potential of Cooperatives to ReEmbed the Economy: A Multiple Case Study of Food Cooperatives in Belgium”, Working Paper CIRIEC No. 2018/05.

Wright, E.O. (2012), “Transforming Capitalism through Real Utopias”, American Sociological Review, Vol. XX No. X, pp. 1-25.

Young, D.R., Kerlin, J.A., Teasdale, S. and Soh, J.-I. (2012), “The Dynamics and Long-Term Stability of Social Enterprise”, in Kickul, J.R. and Bacq, S. (Eds.), Patterns in Social Entrepreneurship Research, Edward Elgar Publishing, Cheltenham, UK ;

Northampton, MA, pp. 217-241. 
${ }^{\text {i }}$ See www.fairshares.coop/

${ }^{i i}$ A very interesting example of a voluntary code can be found in Scotland: see www.se-code.net 